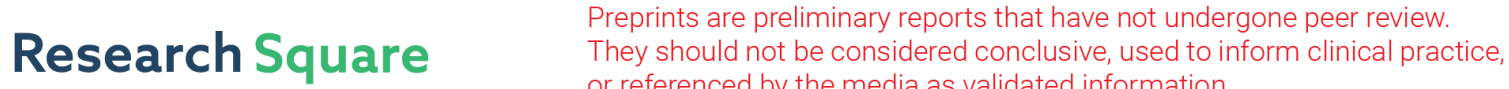 or referenced by the media as validated information. \\ Relational Capital And Strategic Orientations As Antecedents of Innovation: Evidence From Mexican SMEs
}

EDGAR ROGELIO RAMIREZ-SOLIS ( $\sim$ edgar.ramirez@tec.mx )

Tecnológico de Monterrey https://orcid.org/0000-0002-4507-3698

Joan Llonch

Universidad Autónoma de Barcelona: Universitat Autonoma de Barcelona

Alberto Malpica-Romero

Tecnologico de Monterrey: Instituto Tecnologico y de Estudios Superiores de Monterrey

\section{Research}

Keywords: Relational Capital, Strategic Orientations, Innovation, Mexico, SMEs

Posted Date: November 19th, 2021

DOI: https://doi.org/10.21203/rs.3.rs-1074107/v1

License: (c) (i) This work is licensed under a Creative Commons Attribution 4.0 International License.

Read Full License 


\title{
Relational Capital and Strategic Orientations as Antecedents of Innovation: Evidence from Mexican SMEs
}

\author{
*Edgar R. Ramírez-Solis
}

Tecnologico de Monterrey, Departamento de Gestión y Liderazgo, Av. Gral. Ramón

Corona 2514, Col. Nuevo México, Zapopan Jal. 45201, México. Tel +(52)333669-3000 Email: edgar.ramirez@tec.mx

\section{Joan Llonch-Andreu}

Universidad Autónoma de Barcelona. Business Economics Department.

Faculty of Economics. Building B- Campus UAB. 08193- Bellaterra (Barcelona). Spain. Tel. +(34) 93 5812269, Fax +34 935812555 E-mail: joan.llonch@uab.es

\section{Alberto D. Malpica-Romero}

Tecnologico de Monterrey, Departamento de Gestión y Liderazgo, Av. Gral. Ramón Corona 2514, Col. Nuevo México, Zapopan Jal. 45201, México. Tel +(52)333669-3000 Email: alberto.malpica@tec.mx

*Corresponding author 


\begin{abstract}
Despite the importance of strategic orientations and relational capital in businesses, little research has been carried out on the relationship of these factors with the innovation process. Nor has the behavior of strategic orientations been sufficiently studied if we measure them together. This paper examines the relationship between those factors with firm performance. We propose relational capital as a source of innovation for small- and medium-sized enterprises (SMEs) through strategic orientations. Therefore, this study contributes to advanced knowledge in the SMEs competitive research stream. A total of 360 respondents completed a survey conducted at four main cities in México. Using the structural equation modeling (SEM) technique, our results reveal a strong positive effect of relational capital over strategic orientations. Mixed findings of strategic orientations and innovation are presented. The findings offer managerial insights for managers to improve performance through innovation and strategic orientations using relational capital.
\end{abstract}

\title{
Keywords
}

Relational Capital, Strategic Orientations, Innovation, Mexico, SMEs

\section{Introduction}

The changing and turbulent post-pandemic scenario make small and medium enterprises (SMEs) more innovative in running their businesses. Now, more than ever, SMEs need to increase their relationship with many publics, such as customers, business partners, suppliers, business associations, and government, to support their networks. Nevertheless, little research has been done linking innovation to relational capital (Onofrei et al. 2020).

Based on the resource-based vision (RBV), previous research on SMEs has shown that strategic orientations and innovation play a critical role in improving the performance of SMEs (Martin \& Javalgi, 2016; Alnawas \& Abu Farha, 2020). In addition, marketing capabilities have also been shown to represent an essential implementation mechanism for translating strategic directions into superior performance (Kirca et al., 2005; O'Cass \& Heirati, 2015). However, even though this line 
of research has been fundamental to advance in the understanding of the relationship between strategic orientations, capabilities, and performance, the studies have focused mainly on strategic orientations such as entrepreneurial (Martin \& Javalgi, 2016), market (Merrilees et al., 2011) and learning orientations (Sanzo et al., 2012). They have paid little attention to the role of other orientations and the relationship with relational capital or innovation.

There is enough evidence in the literature that proves innovation has a strong and positive influence on different business factors such as productivity (Ramstad, 2009), the performance of processes (Carmeli et al., 2010), organizational learning (Purcarea et al., 2013) and financial performance (Evangelista \& Vezzani, 2010; Bowen et al., 2010). However, previous evidence suggests that the focus of empirical research in SMEs is limited (Rosli \& Sidek, 2013; Maldonado et al., 2020).

Research in innovation related to SMEs has been done in different aspects. For example, Gu et al. (2016) present the effect of internal and external sources on innovation. Gao and Hafsi (2015) examined the impact of business owners' characteristics on their firms. Bala Subrahmanya (2015) established the characteristics of innovative SMEs. Finally, Battistella et al. (2015) proposed a methodology for the implementation of technology in SMEs. In any case, the relationship between strategic orientations and relational capital, as elements that can promote innovation in SMEs, has not been analyzed to date.

Many studies focus on the creation of relational capital within a company and its impact on performance; The relational capital impacts all business-related practices and has become a critical mechanism to sustain competitive advantage (Yu \& Huo, 2019; Zhao et al., 2019). However, relational capital and strategic orientations as innovation antecedents are not well studied in the existing literature.

Our study contributes to this knowledge gap unraveling the mechanisms of relational capital and strategic orientations and explaining how they can support innovation processes. The rest of the article is organized as follows: we review the literature related to relational capital, strategic orientations, and innovation; based on this review, we develop the conceptual framework and the 
associated hypothesis. Then, we present the research methodology, followed by analysis and results. Finally, we conclude with discussions, conclusions, and future research lines.

\section{Theoretical Background and Hypotheses Development}

\section{Relational capital and market orientation.}

Relational capital is one of the three categories of intellectual capital. Relational capital can be defined as the set of all relationships, power relationships and cooperation, established between firms, institutions, and people that stem from a strong sense of belonging and a highly developed cooperation capacity (Capello \& Faggian, 2005).

As we mentioned, few studies are found relating strategic orientations and relational capital. However, following Capello and Faggian's (2005) definition for relational capital, we can link it to the essence of marketing in the relationship of value interchange for the market.

Evidence shows that relational capital is a fundamental asset for firms, particularly SMEs (Welbourne \& Pardo-del-Val, 2009; Corvino et al., 2019). From an economic point of view, a network of solid relationships enables the participants to work with much lower transaction costs. Moreover, through them, smaller companies can become much more efficient than larger competitors. Marketing research has already highlighted the importance of inter-organizational relationships and networks for a firm's survival and success (Day, 2000). Therefore, it has been argued that relationships are a firm's most valuable resource.

Companies design boundaries to protect internal capabilities and resources from an unintended spillover. Therefore, firms establish alliances using interpersonal ties. Through collaborations, social connections across network boundaries lower the hierarchical barrier, thus improving the dissemination and use of information and enabling more effective implementation of market orientation (MO).

As marketing in the behavioral perspective is about action, it is needed to translate the MO activities into relationship management activities (Helfert et al., 2002). Febrian et al. (2020) found a significant effect of relational capital on SMEs networking and marketing performance. Organizations that value 
and leverage existing relational capital have achieved success in the markets, so the hypothesis is developed as follows:

H1: Relational capital is positively related to market orientation

\section{Relational capital and entrepreneurial orientation.}

Entrepreneurial orientation (EO) is defined as the firms' processes, structures, and behaviors characterized by innovation, proactiveness, and risk-taking (Covin \& Slevin, 1988). The proponents of EO suggest that this orientation is better able to adjust their operation in dynamic competitive environments (Covin \& Slevin, 1989), resulting in positive effects on firm performance (e.g., Hult et al., 2004; Wiklund \& Shepherd, 2005). Research has suggested that the interplay between EO and other strategic orientations may provide organizations with sustained competitive advantages (Hult et al., 2004). In addition, companies that balance several orientations perform better (Atuahene-Gima \& Ko, 2001; Bhuian et al.).

Matsuno, Mentzer, and Özsomer (2002) also find that EO positively affects firm performance combined with MO. These authors encourage additional research to inquire into how firms implement strategic orientations, such as organizational learning. Im and Workman (2004), for their part, find that customer orientation is the driving force of new product success, despite its negative effect on new product novelty. They recommend further studies to examine innovation and its performance implications directly and with other intangible assets, such as entrepreneurship.

Several authors have also asserted the significant role of networks in influencing entrepreneurial processes and outcomes (Butler et al., 2003; Hoang \& Antoncic, 2003). Entrepreneurship theory implies that the fundamental of entrepreneurship is the ability to detect, willingness to pursue, and exploit the opportunity in the marketplace (Shane \& Venkataraman, 2000).

Entrepreneurship is naturally a networking activity, and relationships are considered one of the most potent assets since it provides access to power, information, knowledge, technologies, and capital (Elfring \& Hulsink, 2003; Inkpen \& Tsang, 2005). Then can be hypothesized:

H2: Relational capital is positively related to entrepreneurial orientation. 


\section{Relational capital, learning orientation, and innovation.}

Learning orientation (LO) is viewed as the organization's propensity to create and use knowledge to attain competitive advantage (Calantone et al., 2002; Wang, 2008; Chiou \& Chen, 2012). Baker and Sinkula (1999b) address that LO is a mechanism that directly affects the firm's ability to defy old assumptions about the market and how a firm should be organized to deal whit it. Hult et al. (2004) argue that learning orientation occurs primarily at the cultural level of the firm. LO contributes to a firm's innovation capability, and innovation is nurtured from inside and outside the company (Chiou \& Chen, 2012).

Learning is one of the fundamental mechanisms to generate new knowledge and is often an express purpose of collaborative relationships (Mohr \& Sengupta, 2002). Moreover, relational capital encompasses relationships built on a history of trust, respect, and friendliness. Therefore, it seems possible that such aspects would facilitate tacit knowledge sharing, thereby assisting in a more significant range of future opportunity exploitation possibilities among companies (Schenkel \& Garrison, 2009).

Not all entrepreneurs have the capabilities and sufficient resources to exploit external opportunities. Therefore, they need collaboration with the economic actors to carry out activities to access resources and markets. Consequently, they need to develop business networks to exploit new opportunities, obtain more learning, and benefit from the synergistic effect of pooled resources.

In the network environment, firms' LO reflects either exploration in seeking effectiveness through new business development or exploitation in seeking efficiency in their current business. Then can be hypothesized:

H3: Relational capital is positively related to a learning orientation.

Learning in SMEs is context-sensitive, firm-specific, and work-based, producing operational efficiency in the short run (Keskin, 2006, Badger et al., 2001), indicating "reaction" more than innovation. On the other hand, Calantone et al. (2002) sustain that an organization committed to learning can enhance its innovation. Therefore, we hypothesized: 
H7: Learning orientation is positively related to innovation.

\section{Relational capital, technology orientation, and innovation.}

The concept of a technology-oriented firm is explicitly presented by Gatignon and Xuereb (1997). Technology orientation (TO), or the related terms of innovation and product orientation (Grinstein, 2008b), refers to a firm's inclination to introduce or use new technologies, products, or innovations. A TO improves business or new product performance, but studies have not consistently identified positive effects (Hakala, 2011). Creativity and invention are the organizational norm and values that guide a TO firm's activities and strategies (Zhou et al., 2005).

In an SME context, firms tend to cooperate beyond their scope with other organizations -large and small- to exploit new technologies in networks (Širec \& Bradač, 2009), understanding networks as the connections and interactions between individual groups and organizations.

Some studies have examined and understood how collaborative networks foster research and technology development (e.g., Protogerou et al., 2013). Saqib et al. (2018) researched the relationship between TO and innovation, and they found an insignificant impact of innovativeness on the performance of manufacturing SMEs. They suggested promoting collaboration among SMEs (relational capital), reviewing government legislation, and supporting the SMEs.

Moreover, managerial networking has evolved as a critical concept in understanding how top management is linked up with stakeholders and how these relationships (relational capital) contribute to their businesses in different aspects (Panda, 2014). Thus, it can be hypothesized:

H4: Relational capital is positively related to technology orientation.

It has been found that technology-oriented firms heavily invest in research and development and usually accept the "state of the art" of technology, encouraging employees to propose new radical ideas creating a "breakthrough innovation" culture. Lumpkin and Dess (1996) suggested a similar perspective. They asserted that an entrepreneurial spirit of creating new businesses and breakthrough innovations could renew stagnant companies. Then can be hypothesized:

H8: Technology orientation is positively related to innovation. 


\section{Market orientation and innovation.}

Market orientation (MO) has been defined as a set of ongoing behaviors and activities related to generation, dissemination, and responsiveness to market intelligence (Jaworski \& Kohli, 1993). In addition, Narver and Slater (1990) assert that MO refers to a culture that prioritizes creating buyer value. Thus, $\mathrm{MO}$ is an aspect of culture and is a latent construct whose indicators are values, beliefs, and symbols that demonstrate a concern for markets (Hult et al., 2004).

Innovation is most frequently used to measure the degree of "newness" (Calantone \& Garcia, 2002), and most of the research takes a firm's perspective toward newness related to the market. Innovativeness relates to a firm capacity to engage in innovation, meaning the introduction of new processes, ideas, or products (Hult et al., 2004) to be launched with a specific market in mind.

MO has been criticized in the context of tech startups - which typically focus on innovation - because customers in this industry express their needs without paying attention to long-term thinking (Renko et al., 2009). However, some studies show that this is not always true (Narver et al., 2004).

A significant amount of literature has established a positive relationship between MO and innovation (Grinstein, 2008b; Renko et al., 2009; Beck et al., 2011). For example, Beck et al. (2011) found that the positive relationship between $\mathrm{MO}$ and innovation is maintained in a family firm sample through several generations. The generation in control influences innovation through its influence on MO. Then can be hypothesized:

H5: Market orientation is positively related to innovation.

\section{Entrepreneurial orientation and innovation}

Miller (1983) describes entrepreneurial orientation (EO) as emphasizing aggressive innovation, risky projects, and a predisposition to pioneer innovations. EO has long been associated with proactive competitive posture, management proclivity for risky projects, and the firm necessity to engage in innovative actions to achieve objectives (Covin \& Slevin, 1989). It is also suggested that EO leads to new venture-product creation, fostering new businesses, or reviving inactive firms. 
Avlonitis and Salavou (2007) suggest that those entrepreneurs adopting an orientation characterized by risk-taking and a proactive competitive attitude tend to introduce new, highly unique products. Also, Zhou et al. (2005) found that entrepreneurial orientation positively affects breakthrough innovations. However, the EO literature has made no differences between the "new to the firm" or "new to the world" innovations. Pérez-Luño et al. (2011) state that the innovativeness dimension of EO has remained under-conceptualized and concluded that EO is related to "new to the world" innovation rather than to "new to the firm." In other words, only the launch of "new to the world" products appears to result from their EO. Therefore, we can hypothesize:

H6: Entrepreneurial orientation is positively related to innovation.

\section{Innovation and firm performance}

Schumpeter's theory of profit extraction supports the traditional explanation for the positive relationship between firm innovation and performance, which sustains that innovative companies gain a temporary quasi-monopoly, enabling them to extract rents (Rubera \& Kirca, 2012).

It is also known that highly innovative firms can develop creative solutions that undermine those of their competitors (Hughes \& Morgan, 2007). Firms want to maintain their market power through continuous innovations, trying to sustain a superior performance with multiple product introductions. Innovation positively contributes by attenuating the natural forces of competition or changing the consumption patterns that tend to dissipate superior returns over time (Sharma \& Lacey, 2004). Previous studies have already examined the relationship between innovation and business performance (e.g., Hult et al., 2004; Olavarrieta and Friedmann, 2008; Rhee et al., 2010). In a metaanalysis, Bowen et al. (2010) found that the temporal sequence of research designs has often been flawed in previous empirical studies of both causal directions of the organizational performance and innovation relationship. When they corrected the studies based on the actual temporal sequence used, they found a positive relationship between innovation and future performance. However, past performance and innovation are less clear. Then can be hypothesized:

H9: Innovation is positively related to firm performance. 
Figure 1 shows the model proposed with all the hypotheses:

\section{INSERT FIGURE 1 ABOUT HERE}

\section{Methodology}

A random sample of small and medium enterprises (SMEs) in México provides the empirical setting for this research. Thus, 360 companies from the service, industry, and commerce sectors were interviewed in four principal cities: México City, Guadalajara, Monterrey, and Puebla. Table 12 shows the official classification in México regarding SMEs. Professional interviewers of a renowned Mexican-polling firm applied one-by-one questionnaires to firm directors, business owners, and businesses responsible during February 2019.

All constructs were measured using Likert-type scales with a five-point response format anchored by "strongly disagree" to "strongly agree" unless otherwise noted. Independent variables will be discussed first, followed by the description of the dependent variables and the control. All $\alpha$ values showed acceptable values with $\alpha>0.769$.

An adapted six-item scale based on Delgado-Verde et al. (2011) was used to measure relational capital. The scale represents the ability to measure the relationships between clients and suppliers. To measure the market orientation, we used a scale based on Narver and Slater (1990). In addition, extensive research -conceptual and empirical- has been done regarding market orientation, emphasizing this orientation's focus on customers (Deshpandé et al., 2013). An adapted scale based on Baker and Sinkula (1999b) was used to measure entrepreneurial orientation. To measure learning orientation, we used an adapted scale based on Sinkula et al. (1997). An adapted five-item scale based on Gatignon and Xuereb (1997) was used to measure technology orientation. The scale represents the ability and willingness of an organization to develop new technologies and the usage of sophisticated technologies (Gao et al., 2007). An adapted three-item scale based on Baker and Sinkula (1999a) was used to measure innovation. The ranking considers three basic concepts: new products launching, degree of differentiation of innovations, and degree of success of new products. 
Finally, a scale based on diverse authors was used to measure performance (Jaworski \& Kohli, 1993; Narver \& Slater, 1990). It includes financial, customer satisfaction, employee satisfaction, and operations aspects. Subjective measures of performance have been shown reliable and valid when objective data is not available, like in SMEs case (Dess \& Robinson, 1984).

\section{Analysis and Results}

The first step was an exploratory factor analysis using IBM SPSS Statistics 21 to validate each proposed construct. After the exploratory analyses, we use a structural equation modeling technique (SEM). This technique is widely used by marketing researchers (Uribe et al., 2013 p. 217) and combines the Confirmatory Factor Analysis (CFA) and multiple regressions. In addition, it allows researchers to analyze relationships between observed and no observed variables (constructs) (Schreiber et al., 2006).

The structural model shows the relationships between the different latent variables (constructs). The measurement model shows the relationships between latent variables and the observed variables used to measure latent variables. Figure 2 shows the CFA for the model proposed. Again, AMOS 21 was used to conduct CFA analysis.

INSERT FIGURE 2 ABOUT HERE

Table 1 shows the results for the Reliability, Convergent, and discriminant validity of the model.

INSERT TABLE 1 ABOUT HERE

Table 2 shows the relationship between variables in the proposed model. In this table can be seen that: i) there exist a direct and positive effect of relational capital over market orientation, supporting hypothesis 1 ; ii) there exist a direct and positive effect of relational capital over entrepreneurial orientation, supporting hypothesis 2 ; iii) there exist a direct and positive effect of relational capital over learning orientation, supporting hypothesis 3; iv) there exist a direct and positive effect of relational capital over technology orientation, supporting hypothesis 4 ; v) there exist a direct and 
positive effect of market orientation over innovation, supporting hypothesis 5; vi) there exists a direct and positive effect of entrepreneurial orientation over innovation, supporting hypothesis 6; vii) there exist a direct and negative effect of learning orientation over innovation, not supporting hypothesis 7: viii) there is no significant relationship between technology orientation and innovation, not supporting hypothesis 8 and ix) there is a direct and positive effect of innovation over performance, supporting hypothesis 9 .

INSERT TABLE 2 ABOUT HERE

Figure 3 shows the SEM analysis result,

INSERT FIGURE 3 ABOUT HERE

\section{Discussion and Conclusions}

The proposed hypothesized model was widely supported, suggesting that theories typically applied to developed economies can be used to emerging economies and SMEs. Despite the different model proposed, a positive relationship between innovation and firm performance in SMEs were confirmed. Woodside (2005) mentions that analyses should advance from the one-directional structural equation modeling of innovation and business performance to a systems dynamic modeling that includes more real feedback looped models.

A significant finding of this investigation is the direct and positive relationships between relational capital and strategic orientations. As was stated before, little research has been done regarding this type of relationship. However, as Teece (2007) mentioned, strategic orientations can be seen as dynamic capabilities for the organization, and diverse antecedents can be found. Therefore, it is remarkable that all of the hypotheses $-\mathrm{H} 1$ through $\mathrm{H} 4$ - were supported with $\mathrm{p}<0.01$.

Market orientation is one of the most studied strategic orientations in the marketing literature (Kirca et al., 2005); however, few empirical studies have researched its relationship with relational capital. Entrepreneurial processes have been identified as the collaborative process according to Butler et al. (2003). The empirical results obtained from this study confirm this assertion. It also follows what 
was stated as supporting this hypothesis: entrepreneurs need collaboration with different business actors to gain access to resources and markets.

Learning orientation and relational capital have been explored in specific contexts. For example, Liu et al. (2010) found a positive relationship between these two constructs in an alliance scenario. Our results show that this finding can be extended into the SMEs context. However, few empirical studies can be found, so more research is needed to advance this relationship's understanding.

In the relationship between technology orientation and relational capital, we found a strong positive relationship; this result suggests that interactions with different business actors could foster technology in SMEs.

The direct but negative relationship between learning orientation and innovation is quite a surprising finding, but learning in SMEs is context-sensitive, firm-specific, and work-based, producing operational efficiency in the short-run (Keskin, 2006, Badger et al., 2001), indicating "reaction" more than innovation. This idea could be one of the potential explanations for this finding. However, several studies found a positive relationship between learning orientation and innovation (Calantone et al., 2002). Therefore, another possible explanation is that some other factors should be considered to understand the negative relationship in the SMEs context. More research must be done.

Another finding that needs to be discussed is the non-significant relationship between technology orientation and innovation. Zhou and $\mathrm{Wu}$ (2009) comment that mixed results can be found in this relationship because of the assumption of a linear relationship between technological capability (technology orientation) and explorative innovation. They found that though technological capability fosters innovation exploitation at an accelerating rate, it has an inverted U-shaped relationship with innovative exploration; that is, a high level of technological capability impedes explorative innovation. More research is needed to be performed to understand this finding better.

Much discussion can be found in market orientation literature regarding the contribution of this orientation to innovation. Many studies reveal a non-significant contribution or even a negative relationship due to the nature of market orientation. This study shows a positive relationship contributing to the debate. 
Finally, a positive relationship between entrepreneurial orientation and innovation was found. This result is consistent with other studies that show similar results (Tajeddini, 2010).

This study provides several managerial implications for SMEs to enhance their performance. First, empirical results confirm innovation as a determinant of business performance; this implies that innovative activities are crucial for success. Consequently, managers are advised to improve innovation in their businesses with the correct investments and efforts to achieve superior business performance.

Results also show a positive relationship between relational capital and strategic orientations. Therefore, a piece of advice to SMEs managers is to pay attention to their relational capital and the broader concept named intellectual capital.

\section{Limitations and implications for future research}

Some limitations can be identified as well as future research streams. One of them has to deal with the cross-sectional nature of the study. In addition, strategic orientations are not static but rather evolve, so this may not reflect the dynamics of changes and their potentially lagged influence on performance (Wiklund \& Shepherd, 2005). However, one reason can be argued against this limitation; some longitudinal studies suggest that the effect of strategic orientations on performance displays somewhat similar results (Dawes, 2000). Nonetheless, a longitudinal research design undoubtedly will provide a more insightful result about the effects of evolving strategic orientations and their influence on SMEs performance over time. So then, one future line for research is to perform longitudinal studies that could capture the changing nature of strategic orientations and their effect on firm performance.

Another significant limitation is that findings in the study are based on a single country data and, although México shares many characteristics with other emerging economies, results cannot be generalized. Therefore, we suggest designing new research in other emerging economies to contrast this study's findings.

The sample used for the study includes companies from the commerce, industry, and service sectors. The methodology used for the survey addresses them in a general sense, impeding to conclude a 
specific industry. Alternative analysis techniques like multiple group analysis can be suggested for future studies.

Another limitation of the study is the single respondent bias effect. Different points of view regarding this can be found in the literature; Snow and Hrebiniak (1980) affirm that top managers have the best idea of the entire organization, while Hambrick (1981) strongly advises using only the CEO for responses. Bowman and Ambrosini (1997) found that data collected by only one respondent may not be reliable. We can suggest that future research could use more than one respondent to contrast results.

Additional research can be designed to expand the proposed model, including other essential firm resources and capabilities such as physical assets. Environmental factors or physical location can also be considered.

Strategic orientations per se do not automatically lead to superior performance; consequently, further research should identify the underlying action components to understand how strategic orientations work.

Technology orientation and innovation can sometimes be considered closely related terms (Grinstein, 2008a). However, even that statistical evidence shows that both constructs are well identified, these two phenomena are difficult to distinguish in practice. One result of this research is that technology orientation does not have a significant relationship with innovation. A future research line regarding this is to encourage researchers to design more differentiated measurements for technology orientation and innovation.

Another future research line can be derived from the negative relationship between learning orientation and innovation. A call to design new research studies is made to contrast this result.

\section{List of Abbreviations}

\begin{tabular}{|c|l|}
\hline Abbreviations & \multicolumn{1}{|c|}{ Explanation } \\
\hline CFA & Confirmatory Factor Analysis \\
\hline EO & Entrepreneurial Orientation \\
\hline
\end{tabular}




\begin{tabular}{|c|l|}
\hline LO & Learning Orientation \\
\hline MO & Market Orientation \\
\hline RBV & Resource-based Vision \\
\hline SEM & Structural Equation Modeling \\
\hline SMEs & Small and Medium Enterprises \\
\hline TO & Technology Orientation \\
\hline
\end{tabular}

\section{Declarations}

Availability of data and materials: The data supporting this study's findings are available from the corresponding author, Edgar Ramírez-Solís, upon reasonable request.

Competing interests or conflict of interest: The authors certify that they have NO affiliations with or involvement in any organization or entity with any financial interest (such as honoraria; educational grants; participation in bureaus; membership, employment, consultancies, stock ownership, or other equity interest; and expert testimony or patent-licensing arrangements), or non-financial interest (such as personal or professional relationships, affiliations, knowledge or beliefs) in the subject matter or materials discussed in this manuscript. Therefore, we have no conflicts of interest to disclose.

Funding: The authors did not receive any funding for this research.

Authors' contributions: The authors contributed equally to the design and implementation of the research, the analysis of the results, and the manuscript's writing.

Acknowledgments: Not applicable.

\section{References}

Alnawas, I. \& Abu Farha, A. (2020), "Strategic orientations and capabilities' effect on SMEs' performance," Marketing Intelligence \& Planning, Vol. 38 No. 7, pp. 829-845.

Atuahene-Gima, K. \& Ko, A. (2001), "An empirical investigation of the effect of market orientation and entrepreneurship orientation alignment on product innovation," Organization Science, 12(1), 54-74.

Avlonitis, G. J. \& Salavou, H. E. (2007), "Entrepreneurial orientation of SMEs, product innovativeness, and performance," Journal of Business Research, 60(5), 566-575.

Badger, I. C., Mangles, T. \& Sadler-Smith, E. (2001), "Organizational learning styles, competencies and learning systems in small, UK manufacturing firms", International Journal of Operations \& Production Management, 21(11), 14171432. 
Bala Subrahmanya, M.H. (2015), "Innovation and growth of engineering SMEs in Bangalore: why do only some innovate and only some grow faster?", Journal of Engineering and Technology Management, Vol. 36 (April-June), pp. 24-40.

Baker, W. E. \& Sinkula, J. M. (1999a), "Learning Orientation, Market Orientation, and Innovation: Integrating and Extending Models of Organizational Performance", Journal of Market-Focused Management, 4(4), 295-308.

Baker, W. E. \& Sinkula, J. M. (1999b), "The Synergistic Effect of Market Orientation and Learning Orientation on Organizational Performance", Journal of the Academy of Marketing Science, 27(4), 411-427.

Battistella, C., De Toni, A.F. \& Pillon, R. (2015), "The extended map methodology: technology road mapping for SMES clusters", Journal of Engineering and Technology Management, Vol. 38 (October-December), pp. 1-23.

Bhuian, S. N., Menguc, B. \& Bell, S. J. (2005), "Just entrepreneurial enough: the moderating effect of entrepreneurship on the relationship between market orientation and performance", Journal of Business Research, 58(1), 9-17.

Butler, J. E., Brown, B. \& Chamornmarn, W. (2003), "Informational Networks, Entrepreneurial Action and Performance", Asia Pacific Journal of Management, 20(2), 151-174.

Bowen, F.E., Rostami, M. and Steel, P. (2010), "Timing is everything: a Meta-analysis of the relationships between organizational performance and innovation", Journal of Business Research, Vol. 63 No. 11, pp. 1179-1185.

Calantone, R.J., Cavusgil, S.T. \& Zhao, Y. (2002), "Learning orientation, firm innovation capability, and firm performance", Industrial Marketing Management 31(6), 515-524.

Calantone, R. \& Garcia, R. (2002), "A critical look at technological innovation typology and innovativeness terminology: a literature review", Journal of Product Innovation Management, 19(2), 110-132.

Capello, R. \& Faggian, A. (2005), "Collective Learning and Relational Capital in Local Innovation Processes", Regional Studies, 39(1), 75-87.

Carmeli, A., Gelbard, R. and Gefen, D. (2010), "The importance of innovation leadership in cultivating strategic fit and enhancing firm performance", The Leadership Quarterly, Vol. 21 No. 3, pp. 339-349.

Chiou, CC. \& Chen, YC. (2012), "Relations among Learning Orientation, Innovation Capital and Firm Performance: An Empirical Study in Taiwan's IT/Electronic Industry", International Journal of Management", 29(3), 321-331.

Corvino, A., Caputo, F., Pironti, M., Doni, F., \& Martini, S. B. (2019). The moderating effect of firm size on relational capital and firm performance: evidence from Europe. Journal of Intellectual Capital. Vol. 20 No. 4, pp. 510-532.

Covin, J.G. \& Slevin, D.P. (1988), "The influence of organization structure on the utility of an entrepreneurial top management style", Journal of Management Studies, 25(3), 217-234. 
Covin, J.G. \& Slevin, D.P. (1989), "Strategic Management of small firms in hostile and benign environments", Strategic Management Journal, 10(1), 75-87.

Day, G. S. (2000), "Managing marketing relationships", Journal of the Academy of Marketing Science, 28(1), 24-30.

Delgado-Verde, M., Martín-de-Castro, G., Navas-López, J.E. \& Cruz-González, J. (2011), “Capital social, capital relacional e innovación tecnológica. Una aplicación al sector manufacturero español de alta y media-alta tecnología”, Cuadernos de Economía y Dirección de la Empresa, 14(4), 207-221.

Dess, G. G., Lumpkin, G.T. \& Covin J. G. (1997), "Entrepreneurial strategy making and firm performance: tests of contingency and configurational models", Strategic Management Journal, 18(9), 677-695.

Dess, GG \& Robinson, R. (1984), "Measuring organizational performance in the absence of objective measures: the case of the privately-held firm and conglomerate business unit", Strategic Management Journal, 5(3), 265-273.

Deshpandé, R., Grinstein, A., Kim. S. \& Ofek, E. (2013), "Achievement motivation, strategic orientations and business performance in entrepreneurial firms: How different are Japanese and American Founders? International Marketing Review, 30(3), 231-252

Elfring, T. \& Hulsink, W. (2003), "Networks in Entrepreneurship: The Case of High Technology Firms", Small Business Economics, 21(4), 409-422.

Evangelista, R. \& Vezzani, A. (2010), "The economic impact of technological and organizational innovations: a firm level analysis", Research Policy, Vol. 39 No. 10, pp. 1253-1263.

Febrian, A. C., Sukresna, I. M., \& Ghozali, I. (2020). Relational capital and marketing performance: The mediating role of SMEs networking in Indonesia. Management Science Letters, 3405-3412.

Gao, G., Zhou, K. \& Yim, C. (2007), "On what should firms focus in transitional economies? A study of the contingent value of strategic orientations in China", International Journal of Research in Marketing, 24(1), 3-15.

Gao, Y. \& Hafsi, T. (2015), "R\&D spending among Chinese SMEs: the role of business owners' characteristics", Management Decision, Vol. 53 No. 8, pp. 1714-1735.

Gatignon, H. \& Xuereb, J. (1997), "Strategic Orientation of the Firm and New Product Performance", Journal of Marketing Research, 34(1), 77-90.

Grinstein, A. (2008a), "The relationships between market orientation and alternative strategic orientations: A metaanalysis", European Journal of Marketing, 42(1-2), 115-134.

Grinstein, A. (2008b), "The Effect of Market Orientation and Its Components on Innovation Consequences: A MetaAnalysis", Journal of the Academy of Marketing Science, 36(2), 166-173. 
Gu, Q., Jiang, W. \& Wang, G.G. (2016), "Effects of external and internal sources on innovation performance in Chinese high-tech SMEs: a resource-based perspective", Journal of Engineering and Technology Management, Vol. 40 (AprilJune), pp. 76-86.

Hakala, H. (2011), "Strategic Orientations in Management Literature: Three Approaches to Understanding the Interaction between Market, Technology, Entrepreneurial and Learning Orientations", International Journal of Management Reviews, 13(2), 199-217.

Helfert, G., Ritter, T. \& Walter, A. (2002), "Redefining market orientation from a relationship perspective: Theoretical considerations and empirical results", European Journal of Marketing, 36(9-10), 1119-1139.

Hoang, H. \& Antoncic, B. (2003), "Network-Based Research in Entrepreneurship: A Critical Review", Journal of Business Venturing, 18(2), 165-187.

Hult, G. T., Hurley, R. F., \& Knight, G. A. (2004), "Innovativeness: Its antecedents and impact on business performance", Industrial Marketing Management, 33(5), 429-438.

Im, S. \& Workman J. P. (2004), "Market Orientation, Creativity, and New Product Performance in High-Technology Firms," Journal of Marketing, 68(2), 114-132.

Inkpen, A., C. \& Tsang, E. W. K. (2005), "Social Capital, Networks, and Knowledge Transfer", Academy of Management Review, 30(1), 146-165.

Jaworski, B. \& Kohli, A. (1993), "Market orientation: antecedents and consequences", Journal of Marketing, 57(3), 53-70.

Keskin, H. (2006), "Market orientation, learning orientation, and innovation capabilities in SMEs: An extended model", European Journal of Innovation Management, 9(4), 396-417.

Kirca, A. H., Jayachandran, S. \& Bearden, W. O. (2005), "Market orientation: a meta-analytic review and assessment of its antecedents and impact on performance", Journal of Marketing, 69(2), 24-41.

Leitner, K. H. (2011), "The effect of intellectual capital on product innovativeness in SMEs", International Journal of Technology Management", 53(1), 1-18.

Liu, C., Ghauri, P. N. \& Sinkovics, R. R. (2010), "Understanding the impact of relational capital and organizational learning on alliance outcomes", Journal of World Business, 45(3), 237-249.

Lumpkin, G.T. \& Dess, GG (1996), "Clarifying the Entrepreneurial Orientation Construct and Linking It to Performance", Academy of Management Review, 21(1), 135-172.

Maldonado-Guzmán, G., Garza-Reyes, J.A., Pinzón-Castro, S.Y. \& Kumar, V. (2020), "Innovation capabilities and performance: are they truly linked in SMEs?", International Journal of Innovation Science, Vol. 11 No. 1, pp. 48-62. 
Martin, L. \& Javalgi, G. (2016), "Entrepreneurial orientation, marketing capabilities and performance: the moderating role of competitive intensity on Latin American international new ventures", Journal of Business Research, Vol. 69 No. 6 , pp. 2040-2051.

Matsuno, K., Mentzer, J. T. \& Özsomer A. (2002), "The Effects of Entrepreneurial Proclivity and Market Orientation on Business Performance," Journal of Marketing, 66(3), 18-32.

Merrilees, B., Rundle-Thiele, S. \& Lye, A. (2011), "Marketing capabilities: antecedents and implications for B2B SME performance", Industrial Marketing Management, Vol. 40, pp. 368-375.

Miller, D. (1983), "The correlates of Entrepreneurship in Three Types of Firms", Management Science, 770-791.

Mohr, J. J. \& Sengupta, S. (2002), "Managing the paradox of inter-firm learning: the role of governance mechanisms", Journal of Business \& Industrial Marketing, 17(4) No. 4, 282-310.

Narver, J. \& Slater, S. (1990), "The effect of a market orientation on business profitability", Journal of Marketing, 54(4), 20-35.

Narver, J.C., Slater, S.F. \& MacLachlan D.L. (2004). "Responsive and Proactive Market Orientation and New-Product Success", Journal of Product Innovation Management, 21(5), 334-347.

O'Cass, A. and Heirati, N. (2015), "Mastering the complementarity between marketing mix and customer-focused capabilities to enhance new product performance", Journal of Business and Industrial Marketing, Vol. 30 No. 1, pp. $60-71$.

Olavarrieta, S., \& Friedmann, R. (2008), "Market orientation, knowledge-related resources and firm performance", Journal of Business Research, 61(6), 623-30.

Onofrei, G., Nguyen, H. M., Zhang, M., \& Fynes, B. (2020). Building supply chain relational capital: The impact of supplier and customer leveraging on innovation performance. Business Strategy and the Environment, 29(8), 3422-3434.

Panda, D. K. (2014), "Managerial Networks and strategic orientation in SMEs: Experience from a transition economy," Journal of Strategy and Management, 7(4), 376-397.

Pérez-Luño, A., Wiklund, J., \& Cabrera, R. V. (2011). The dual nature of innovative activity: How entrepreneurial orientation influences innovation generation and adoption. Journal of business Venturing, 26(5), 555-571.

Protogerou, A., Caloghirou, Y. \& Siokas, E. (2013), "Twenty-five years of science-industry collaboration: the emergence and evolution of policy-driven research networks across Europe," Journal of Technology Transfer, 38(6), 873-895.

Purcarea, I., Benavides Espinosa, MM and Apetrei, A. (2013), "Innovation and knowledge creation: perspectives on the SMEs sector," Management Decision, Vol. 51 No. 5, pp. 1096-1107. 
Ramstad, E. (2009), "Expanding innovation system and policy: an organizational perspective," Policy Studies, Vol. 30 No. 5, pp. 533-553.

Renko, M., Carsrud, A. \& Brännback, M. (2009), "The effect of Market Orientation, Entrepreneurial Orientation, and Technological Capability on Innovativeness: A Study of Young Biotechnology Ventures in The United States and in Scandinavia", Journal of Small Business Management, 47(3), 331-369.

Rhee, J., Park, T., \& Lee, D. H. (2010), "Drivers of innovativeness and performance for innovative SMEs in South Korea: Mediation of learning orientation", Technovation, 30(1), 65-75.

Rosli, MM \& Sidek, S. (2013), "The impact of innovation on the small and medium enterprises: evidence from Malaysia", Journal of Innovation Management in Small \& Medium Enterprise, Vol. 1 No. 1, pp. 1-16.

Rubera, G. \& Kirca, A. (2012), "Firm Innovativeness and Its Performance Outcomes: A Meta-Analytic Review and Theoretical Integration", Journal of Marketing, 76(3), 130-147.

Saqib, M., Zarine, R., \& Udin, Z. M. (2018). Exploring the technology orientation influence on the innovativenessperformance relationship of manufacturing SMEs. International Journal of Innovation and Learning, 24(3), 277-300.

Schenkel, M. T. \& Garrison, G. (2009), "Exploring the roles of social capital and team-efficacy in virtual entrepreneurial team performance", Management Research News, 32(6), 525-538.

Schreiber, J., Nora, A., Stage, F. Barlow, E. \& King, J. (2006), "Reporting structural equation modeling and confirmatory factor analysis results", Journal of Educational Research, 99(6), 323-338.

Shane, S. \& Venkataraman, S. (2000), "The Promise of Entrepreneurship as a Field of Research", The Academy of Management Review", 25(1), 217- 226.

Sharma, A. \& Lacey, N. (2004), "Linking product development outcomes to market valuation of the firm: the case of the US pharmaceutical industry", Journal of Product Innovation Management, 21(5), 297-308.

Širec, K. \& Bradač, B. (2009), "How does Networking Impact the SMEs Growth", Organizacija, 42(2), 59-66.

Slater, S.F., Olson, E.M. \& Hult, T.M. (2006), "The moderating influence of strategic orientation on the strategy formation capability-performance relationship", Strategic Management Journal, 27(12), 1221-1231.

Tajeddini, K. (2010), "Effect of customer orientation and entrepreneurial orientation on innovativeness: Evidence from the hotel industry in Switzerland", Tourism Management, 31(2), 221-231.

Teece, D. (2007), "Explicating dynamic capabilities: The nature and microfoundations of (sustainable) enterprise performance", Strategic Management Journal, 28(13), 1319-1350. 
Uribe, F., Rialp, J. \& Llonch, J.. (2013), "El uso de las redes sociales digitales como herramienta de marketing en el desempeño empresarial”, Cuadernos de Administración, 26(47), 205-231.

Wang, C. C. (2008), "Entrepreneurial orientation, learning orientation, and firm performance", Entrepreneurship Theory and Practice, 32(4), 635-657.

Welbourne, T. M. \& Pardo-del-Val, M. (2009), "Relational capital: strategic advantage for Small and medium-size enterprises (SMEs) through negotiation and collaboration", Group Decision and Negotiation, 18(5), 483-497.

Wiklund, J., \& Shepherd, D. (2005), "Entrepreneurial orientation and small business performance: a configurational approach", Journal of Business Venturing, 20(1), 71-91.

Woodside, A. G. (2005), "Firm orientations, innovativeness, and business performance: Advancing a system dynamics view following a comment on Hult, Hurley, and Knight's 2004 study", Industrial Marketing Management, 34(3), 275279.

Yu, Y., \& Huo, B. (2019). The impact of relational capital on supplier quality integration and operational performance. Total Quality Management \& Business Excellence, 30(11-12), 1282-1301

Zhao, R., Mashruwala, R., Pandit, S., \& Balakrishnan, J. (2019). Supply chain relational capital and the bullwhip effect. International Journal of Operations \& Production Management, 39(5), 658-689.

Zhou, K. Z. \& Wu, F. (2009), "Technological capability, strategic flexibility, and product innovation", Strategic Management Journal, 31(5), 547-561.

Zhou, K. Z., Yim, C. K. \& Tse, D. K. (2005), "The Effects of Strategic Orientations on Technology- and Market-Based Breakthrough Innovations", Journal of Marketing, 69(2):42-60. 
Figure 1. Model proposed

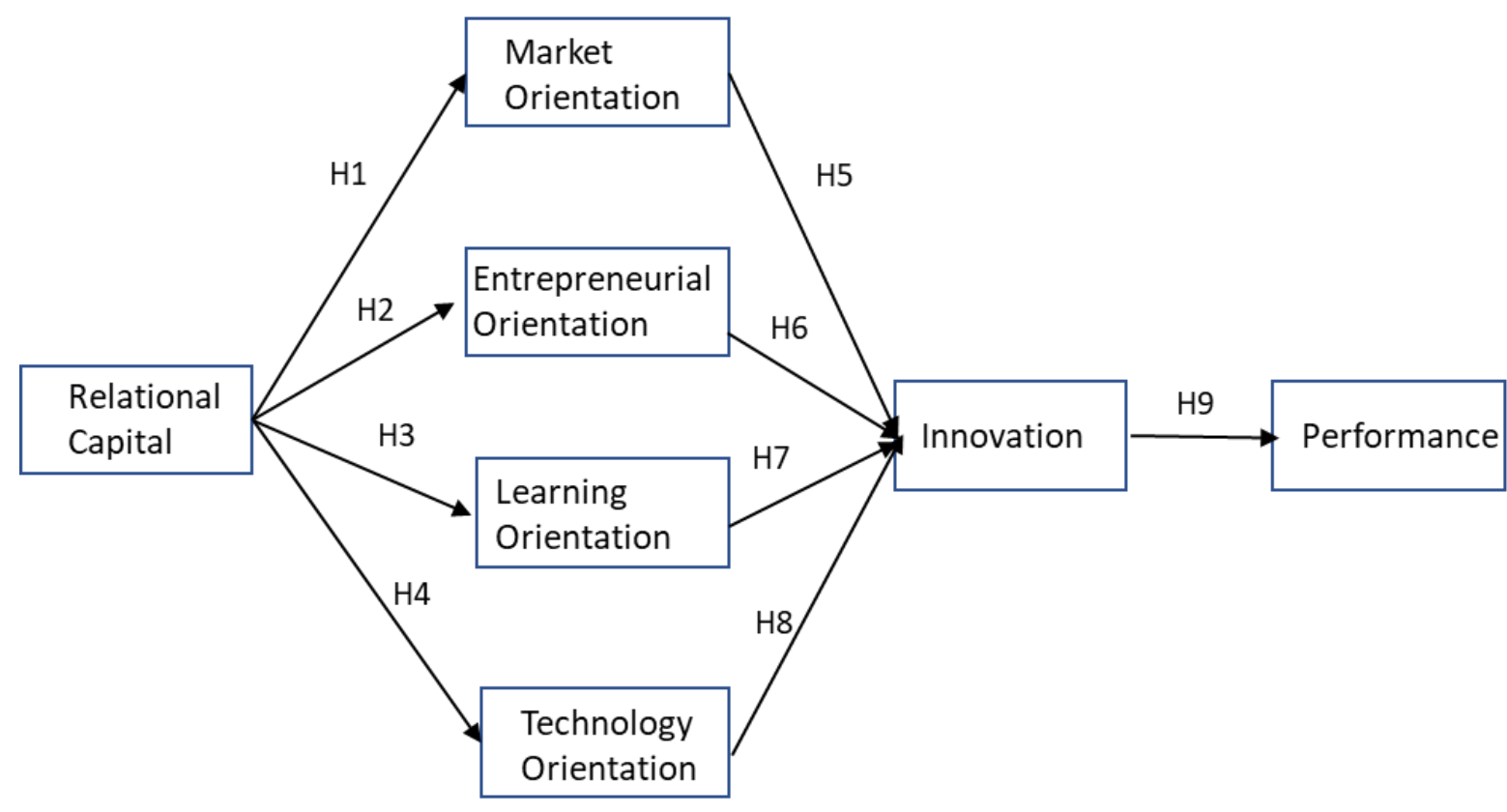

Source: Self-elaborated

Table 1. Reliability, Convergent and discriminant validity $(\mathrm{CR}>0.7, \mathrm{AVE}>0.5 ; \mathrm{CR}>\mathrm{AVE}, \mathrm{MSV}<\mathrm{AVE})$

\begin{tabular}{|c|c|c|c|c|c|c|c|c|c|c|}
\hline & CR & AVE & MSV & LO & PERF & INN & TO & EO & MO & RC \\
\hline LO & $0.576^{*}$ & $0.405^{*}$ & $0.814^{*}$ & $\mathbf{0 . 6 3 6 *}$ & & & & & & \\
\hline PERF & 0.816 & 0.527 & 0.518 & 0.375 & $\mathbf{0 . 7 2 6}$ & & & & & \\
\hline INN & 0.744 & 0.592 & 0.518 & 0.297 & 0.720 & $\mathbf{0 . 7 7 0}$ & & & & \\
\hline TO & 0.712 & 0.553 & $0.601^{*}$ & 0.704 & 0.382 & 0.364 & $\mathbf{0 . 7 4 4} *$ & & & \\
\hline EO & $0.629^{*}$ & $0.365^{*}$ & $0.601^{*}$ & 0.751 & 0.662 & 0.535 & 0.775 & $\mathbf{0 . 6 0 4} *$ & & \\
\hline MO & $0.682^{*}$ & $0.419^{*}$ & $0.814^{*}$ & 0.902 & 0.361 & 0.427 & 0.435 & 0.513 & $\mathbf{0 . 6 4 7 *}$ & \\
\hline RC & 0.760 & 0.515 & $0.596^{*}$ & 0.772 & 0.414 & 0.422 & 0.638 & 0.590 & 0.744 & $\mathbf{0 . 7 1 7 ^ { * }}$ \\
\hline
\end{tabular}

Note: * Values below recommended criteria.

Source: Self-elaborated 
Figure 2. Confirmatory Factor Analysis for the proposed model

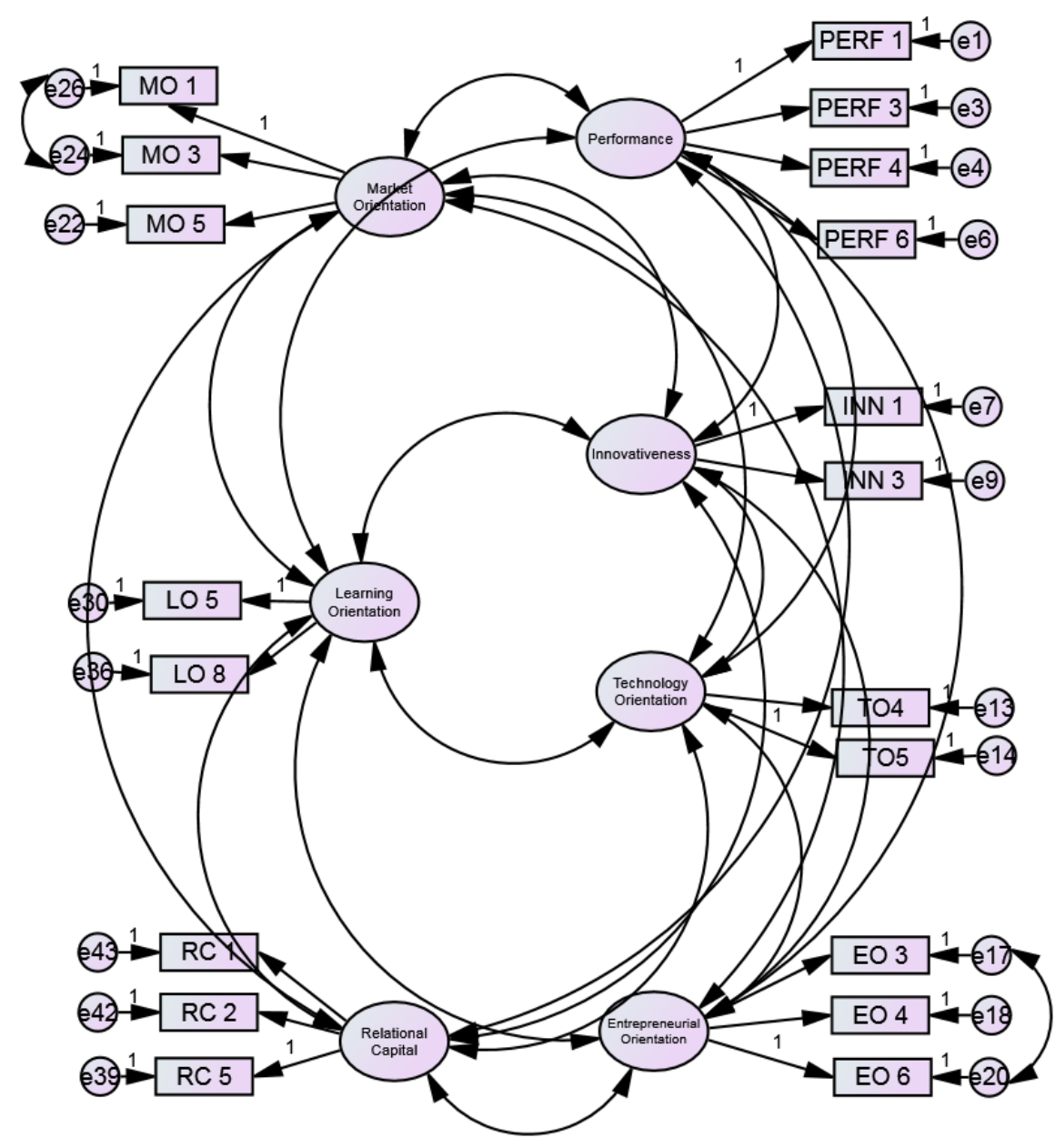

Source: Self-elaborated

Table 2. Relationship between variables in the proposed model

\begin{tabular}{|l|l|l|c|c|c|c|l|}
\hline \multicolumn{3}{|c|}{ Relationships } & Estimate & Std. Estimate & SE. & P & \multicolumn{1}{c|}{ Hypothesis } \\
\hline MO & $<--$ & RC & .908 & .816 & .102 & $* * *$ & H1 is supported \\
\hline EO & $<--$ & RC & .771 & .726 & .107 & $* * *$ & H2 is supported \\
\hline LO & $<--$ & RC & 1.057 & .884 & .115 & $* * *$ & H3 is supported \\
\hline TO & $<--$ & RC & 1.089 & .713 & .130 & $* * *$ & H4 is supported \\
\hline INN & $<--$ & MO & .508 & .398 & .195 & $* *$ & H5 is supported \\
\hline INN & $<--$ & EO & .894 & .668 & .198 & $* * *$ & H6 is supported \\
\hline INN & $<--$ & LO &. .528 & -.445 & .216 & $*$ & H7 is not supported \\
\hline INN & $<--$ & TO & .064 & .068 & .092 & ns & H8 is not supported \\
\hline PERF & $<--$ & INN & .816 & .780 & .079 & $* * *$ & H9 is supported \\
\hline
\end{tabular}

Notes: $\mathrm{N}=360,{ }^{*} \mathrm{p}<0.05 ; * * \mathrm{p}<0.01 ; * * * \mathrm{p}<0.001 ;$ ns: no significant.

Source: Self-elaborated 
Figure 3. The proposed model to SEM

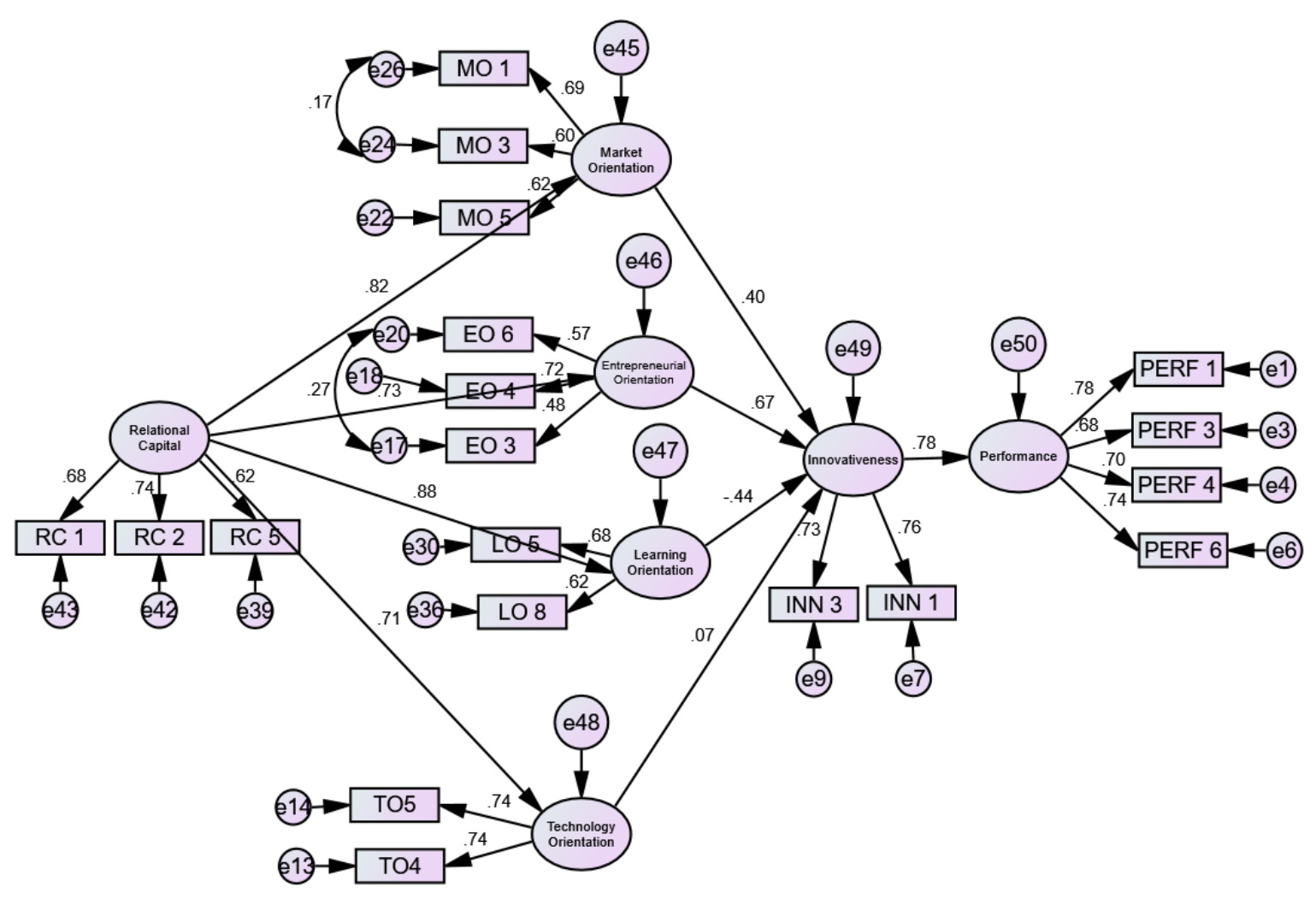

Source: Self-elaborated 